\title{
Molecular diagnosis of the arowanas Osteoglossum ferreirai Kanazawa, 1966 and O. bicirrhossum (Cuvier, 1829) from the Orinoco and Amazon River basins
}

\author{
María Doris Escobar L. ${ }^{1}$, Izeni P. Farias ${ }^{1}$, Donald C. Taphorn B. ${ }^{2}$, Miguel Landines ${ }^{3}$ \\ and Tomas Hrbek ${ }^{1}$
}

\begin{abstract}
The arowanas, fishes of Gondwanan origin, are represented in South America by the genus Osteoglossum. All species were initially reported as being exclusive to the Amazon region, with $O$. ferreirai restricted to the Negro River basin and $O$. bicirrhosum to the Amazon and Essequibo Rivers basin. Starting in the mid 1970's it was reported that $O$. ferreirai also occurs in the Orinoco River basin. In all regions the arowanas assumed significant socio-economic importance due to their popularity in the international ornamental fish trade, leading to over-exploitation of both species in some areas. The Orinoco populations are particularly heavily exploited, and thus conservation and management measures are needed. Both depend on the clarification of taxonomic status, and phylogenetic distinctness of the Orinoco populations. With the goal of molecularly characterizing the two species of Osteoglossum, and comparing populations of Osteoglossum from the Orinoco and Amazon basins, we characterized individuals sampled from eight localities, one in the Orinoco River basin and seven in the Amazon River basin. We sampled 39 individuals, obtaining 1004 base pairs, of which 79 were synapomorphies. Genetic distance between the two species calculated using the HKY $+\mathrm{G}$ model of molecular evolution was $8.94 \%$. Intraspecific distances ranged from $0.42 \%$ in $O$. bicirrhosum to $0.10 \%$ in $O$. ferreirai. The genetic characterization confirmed the taxonomic status of $O$. ferreirai in the Orinoco basin, and suggested that its distribution in the Orinoco basin is unlikely to be the result of vicariance or natural dispersal, but rather an anthropic introduction.
\end{abstract}

Os aruanãs, peixes de origem Gondwana, são representados na América do Sul pelo gênero Osteoglossum. Todas as espécies foram inicialmente reportadas como sendo exclusivamente da região Amazônica, com O. ferreirai restrito a bacia do Rio Negro e $O$. bicirrhosum para a bacia Amazônica e rio Essequibo. No meio dos anos 70 foi reportado que $O$. bicirrhosum também ocorre na bacia do rio Orinoco. Em todas as regiões os aruanãs são de significante importância socio-econômica devido a sua popularidade no comércio internacional de peixes ornamentais, levando a sobre-exploração de ambas as espécies em algumas áreas. As populações no rio Orinoco são particularmente muito exploradas, e assim medidas de conservação e manejo são necessárias. Ambas as medidas dependem de clarificações do estatus taxonômico, e distinções filogenéticas das populações do Orinoco. Com o objetivo de caracterizar molecularmente as duas espécies de Osteoglossum, e comparar as populações de Osteoglossum das bacias do Orinoco e Amazonas, nós caracterizamos indivíduos amostrados de oito localidades, uma da bacia do rio Orinoco e sete da bacia Amazônica. Nós amostramos 39 indivíduos, obtendo 1004 pares de bases, dos quais 97 foram sinapomorfias. A distância genética entre as duas espécies, calculadas usando-se o modelo HKY+G de evolução molecular foi de 8.94\%. Distâncias intraespecíficas variaram de $0.42 \%$ em $O$. bicirrhosum a $0.10 \%$ em $O$. ferreirai. A caracterização genética confirmou o estatus taxonômico de $O$. ferreirai na bacia do rio Orinoco, e sugere que sua distribuição na bacia do rio Orinoco é improvavel de ser o resultado de um evento de vicariância ou dispersão natural, sendo melhor explicada como uma introdução antrópica.

Key words: Aruana, Biological introduction, Black arowana, Silver arowana.

\footnotetext{
${ }^{1}$ Laboratório de Evolução e Genética Animal, Instituto de Ciências Biológicas, Universidade Federal do Amazonas, Manaus, AM, Brazil.tomas@evoamazon.net (TH)

${ }^{2}$ Aquatic Experts, 1822 North Charles Street, Belleville, IL, 62221, USA.

${ }^{3}$ Laboratorio de Fisiología de Peces, Universidad Nacional de Colombia, Bogotá, Colombia.
} 


\section{Introduction}

The osteoglosids, known as the bony tongue fishes, are ancient creatures whose diversification is associated with the breakup of Gondwana (Carroll, 1988; Kumazawa \& Nishida, 2000). Currently, ten species are known with distribution in the following regions: three in South America, one in Africa, four in Asia and two in Australia (Nelson, 2006). In South America, osteoglossids are represented by Arapaima gigas of the family Arapaimidae, and Osteoglossum bicirrhosum and Osteoglossum ferreirai of the family Osteoglossidae, distributed in the Amazonas, Essequibo and Orinoco basins (Reis, et al., 2003; Watkins, et al., 2004; Maldonado-Ocampo, et al., 2008). The existence of arowanas in South America was reported first by the Portuguese naturalist Alexandre Rodriguez Ferreira during expeditions in the Brazilian Amazon between the years 1783 to 1792 . Based on specimens he collected and his illustrations of the white arowana, Cuvier erected the genus and described the species $O$. bicirrhosum. It was Wallace during his 1845 expedition to the Negro River (Brazil) who found and illustrated for the first time the black arowana, however, this individual was lost during his return trip to England. The black arowana was described in 1966 by Kanazawa as Osteoglossum ferreirai, and its distribution was restricted to The Negro River basin, with rest of the Amazon and Essequibo basin being occupied by $O$. bicirrhossum. Based on an ichthyological survey performed by Cala (1973), the range of $O$. ferreirai was expanded to the lower Tomo River in the Colombian Llanos. By the turn of the millennium, $O$. ferreirai was being reported in the Bita, Tomo and Tuparro Vichada Rivers by Mojica (1999), Lasso et al. (2005) and Maldonado-Ocampo et al. (2006; 2008).

The arowanas from the Bita River appear to differ in their reproductive biology from those of the Negro River. A study of Gutiérrez et al. (2009) showed that the Bita River population had lower fecundity, producing 38 to 127 oocites per female and maturing at $62 \mathrm{~cm}$ TL, while in the Negro River populations females produced an average of 136 oocites, and matured sexually at $70 \mathrm{~cm}$ TL (Rabello-Neto, 1999; 2002). These differences were viewed by the authors as indication of population or even species level differences.

The two South American species of arowanas began to be exported in large numbers for the aquarium trade in the 1970's when they started to replace the Asian arowana Scleropages formosus, also known as dragon fish, after $S$. formosus was listed as endangered by CITES (Yue, et al., 2003). Starting in the 1970's, over-exploitation of South American arowanas turned these species threatened with extinction in Colombia (Alvarez-León, 2002a; 2002b). In 2005, Traffic and WWF reunited prominent ichthyologists in the "International Workshop of ornamental fishes from northern South America". They discussed the high vulnerability of both Osteoglossum species, and proposed to include them in Appendix II of CITES. They considered as first action the necessity to clarify the taxonomic status of $O$. ferreirai in the Orinoco basin, its divergence from the Negro basin populations, and an assessment of genetic variability of $O$. bicirrhossum in its area of distribution.

\section{Material and Methods}

We obtained and analyzed fishes caught by artisanal fishermen at these locations: the Orinoco River basin in the Bita River (Puerto Careño, $\mathrm{n}=5$ ), the Amazon River basin: the Negro River (Barcelos, $\mathrm{n}=7$ ), the Putumayo River (Puerto Leguizamo, $n=8$ ), the Juruá River (Eirunepé, $n=5$ ), the Madeira River (Humaita, $n=4$ ) and the Solimões-Amazonas (Tabatinga, $\mathrm{n}=4$; Tefé, $\mathrm{n}=3$; Santarém, $\mathrm{n}=3$ ) Fig. 1 .

All tissue samples were preserved in absolute alcohol and processed in the Laboratório de Evolução e Genética Animal (LEGAL) at the Universidade Federal do Amazonas (UFAM), Manaus, Brazil. DNA extraction was performed with the CTAB method (Doyle \& Doyle, 1987), and quantified by means of electrophoresis in a $0.8 \%$ agarose gel against a known quantity of a molecular size standard (Fermentas).

Subsequently we amplified via the PCR (Polymerase Chain Reaction) a segment of mitochondrial DNA between the 3 ' end of cytochrome oxidase subunit 2 and the $5^{\prime}$ end of the cytochrome oxidase subunit 3, including the tRNA Lysine, and ATPase subunits 6 and 8 . This region was amplified using the primers L8106 5'-TGGGTGTTAAAATAGATGC-3' and H9264 5'-GAGGAGAGCRGCRGATGCCCC-3' and sequenced with L8106, L8537 5'-TGAAACTGACCATGACACTAAG-3' and H8516 5'-CTTGTGTCATGGTCAGTTTCA-3' developed by Hrbek et al. (2005) for Arapaima gigas.

The PCR had a total volume of $15 \mathrm{il}$, and included $5.6 \mu \mathrm{l}$ of $\mathrm{ddH}_{2} \mathrm{O}, 1.2 \mu \mathrm{l}$ of $25 \mathrm{mM} \mathrm{MgCl}_{2}, 1.2 \mu$ of $10 \mathrm{X}$ buffer $(75 \mathrm{mM}$ Tris $\left.\mathrm{HCl}, 50 \mathrm{mM} \mathrm{KCl}, 20 \mathrm{mM}\left(\mathrm{NH}_{4}\right)_{2} \mathrm{SO}_{4}\right), 1.5 \mu \mathrm{l}$ of $10 \mathrm{mM}$ dNTP, 1.5

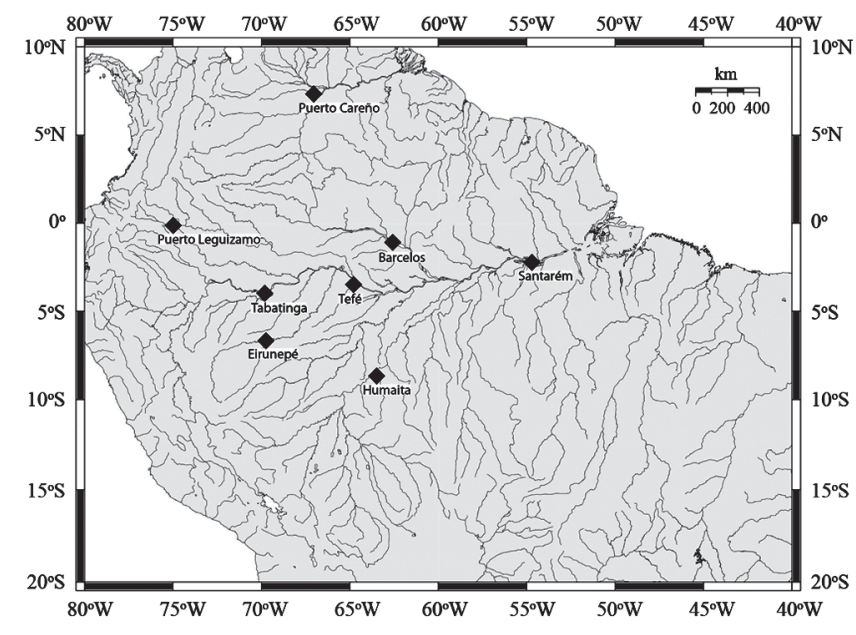

Fig. 1. Sampling localities in the Amazon and Orinoco basins of $O$. bicirrhossum and $O$. ferreirai . Base map was obtained from Online Map Creation (Geomar) currently available as Planiglobe (http://www.planiglobe.com/). 
$\mu l$ of each primer $(2 \mu \mathrm{M}), 1.0 \mu \mathrm{l}$ nuclease-free BSA $(2.5 \mathrm{mg} / \mathrm{ml})$, $0.5 \mu \mathrm{l}$ of Fermentas Taq DNA polymerase $(1 \mathrm{U} / \mu \mathrm{l})$ and $1.0 \mu \mathrm{l}$ DNA ( $20 \mathrm{ng} / \mu \mathrm{l})$.

The PCR reactions were tested on $1 \%$ agarose gel. Sequencing reactions were performed using the BigDye Terminator Kit V.3.1. according to the manufacturer's guidelines and the product was analyzed on an ABI 3130xl automated sequencer. The sequences obtained were viewed and edited by using the program BioEdit (Hall, 1999). The dataset was aligned in Crustal W (implemented within Bioedit) and then adjusted manually (Thompson, et al., 1996). The composition of nucleotide bases, identification of variable sites, stop codons, transversions/transitions and genetic distances was estimated in the program MEGA5 (Tamura, et $a l ., 2011)$. The number and frequency of haplotypes was determined in the program DnaSP v.5 (Librado \& Rozas, 2009).

The program Modeltest 3.7 was used to test for the best molecular evolutionary model fitting the dataset (Posada \& Crandall, 1998). Phylogenetic reconstruction was performed using the maximum likelihood method (ML) implemented in the program Treefinder (Jobb, et al., 2004) and support for relationships was assessed via 1000 bootstrap pseudoreplications. We used Scleropages formosus and Scleropages leichardti as outgroups (Genbank No. DQ023143, FJ890319).

Phylogenetic species were identified using the Population Aggregation Analysis algorithm, that involves a search for fixed differences between local populations, followed by successive rounds of aggregation of populations and previously aggregated population groups that are not distinct from each other (Davis \& Nixon, 1992), and complementary analytical procedures described by Cook et al. (2010).

\section{Results}

The final aligned sequences had a length of $1004 \mathrm{bp}$ and 79 of which were diagnostic for the two species. The 79 synapomorphies were divided between 73 transitions and 6 transversions. The base pair composition of the data set was $\mathrm{A}=27.2 \%, \mathrm{~T}=29.1 \%, \mathrm{C}=30.2 \%, \mathrm{G}=13.4 \%$. In total eleven haplotypes were identified for both species, seven in $O$. bicirrhosum and four in O. ferreirai. In both species a single haplotype was the most frequent (online Supplement 1-3). Haplotypes are available under the GenBank accession numbers JQ436740 to JQ436750.

The maximum likelihood topology using the HKY $+\mathrm{G}$ model of molecular evolution (Posada \& Crandall, 1998) showed the formation of two evolutionary lineages representing the two species. The clade representing $O$. bicirrhosum split into two sub-clades. The first comprised the majority of individuals from the Putumayo (Puerto Leguizamo), Jurua (Eirunepé) and Solimões (Leticia) Rivers and the second was formed by majority of individuals in the Madeira (Humaitá), Solimões (Tefé) and Amazon (Santarém) Rivers. The clade representing O. ferreirai indicated the existence of a single evolutionary lineage consisting of individuals from the Bita (Orinoco basin) and from the Negro (Amazon basin) Rivers (Fig 2). Genetic divergence between the two species of Osteoglossum averaged at $8.94 \%$, while intraspecific divergence in $O$. bicirrhosum was $0.42 \%$ and $O$. ferreirai was $0.10 \%$ (Tables $1-2$ ).

Population Aggregation Analysis (online Supplement) also resulted in the identification and diagnosis of two species:

\section{Osteoglossum bicirrhosum (Cuvier, 1829)}

DNA Diagnosis. This species can be distinguished from $O$. ferreirai by combinations of the following nucleotide characters: COII region: 528T, 561C, 567C, 582A, 585G, 603C, 606C, 612T, 618C, 648G. Lysine tRNA region: 22T, 41C, 45G. ATP8 region: 6A, 12C, 15T, 27G, 30A, 33G, 37T, 54G, 72C, 84C; 112A. ATP6 region: 87C, 96C, 111C, 114C, 138A, 150T, 192G, 198C, 213T, 217T, 219T, 226G, 249C, 258G, 265T, 267A, 282C, 285A, 294G, 300G, 312G, 313T, 318G, 324A, 330G, 333C, 339T, 351T, 363A, 393 T, 394G, 410C, 429C, 447C, 448C, 450C, 474G, 489T, 495C, 508T, 528C, 552T, 576G, 583A, 585T, 586T, 591T, 600A, 607C, 625G, 627T, 633A, 654G, 657A.

Morphological features (data from Kanazawa, 1966). Tip of snout to anus 45.5 to 53.2 ; snout to origin of dorsal fin 55.9 to 61.9 ; snout length 3.7 to 6.5 ; eye diameter 3.1 to 8.7 ; head length 19.6 to 26.9 ; body depth 14.6 to 20.7 . These data are given in percentages with respect to standard length. Branched dorsal fin rays 42 to 50 ; unbranched anal fin rays 49 to 58 ; pectoral rays i, 6; scales along the lateral line to base of caudal fin 30 to 37; pre-dorsal scales 16 to 19 . Adult color is varied and can be silver, yellow, or dark greenish, paler ventrally.

Distribution. Essequibo River basin; Amazon River basin not including the Negro River basin except its Branco River affluent.

\section{Osteoglossum ferreirai Kanazawa, 1966}

DNA Diagnosis. This species can be distinguished from $O$. bicirrhosum combinations of the following nucleotide characters: COII region: 528C, 561T, 567T, 582G, 585A, 603T, 606T, 612C, 618T, 648A. Lysine tRNA region: 22C, 41T, 45A. ATP8 region: 6G, 12T, 15C, 27A, 30G, 33A, 37C, 54A, 72T, 84T, 112G. ATP6 region: 87T, 96C, 111T, 114T, 138G, 150C, 192A, 198T, 213C, 217C, 219A, 226A, 249T, 258A, 265C, 267G, 282T, 285C, 294A, 300A, 312A, 313C, 318A, 324C, 330A, 333T, 339C, 351G, 363G, 393A, 394A, 410T, 429T, 447T, 448T, 450A, 474T, 489C, 495T, 508C, 528T, 552C, 576A, 583G, 585C, 586C, 591C, 600G, 607T, 625A, 627C, 633G, 654A, 657G.

Morphological features (data from Kanazawa, 1966). Tip of snout to anus 48.5; snout to origin of dorsal fin 53.6; snout length 6.4; eye diameter 7.0; head length 22.6; body depth 13.9. These data are given in percentages with respect to standard length. Branched dorsal fin rays 52 to 57 ; unbranched anal fin rays 61 to 66; pectoral rays i, 6; scales along the lateral line to base of caudal fin 37 to 40; pre-dorsal scales 15 to 19 . Adult color is dark bluish, paler ventrally. 


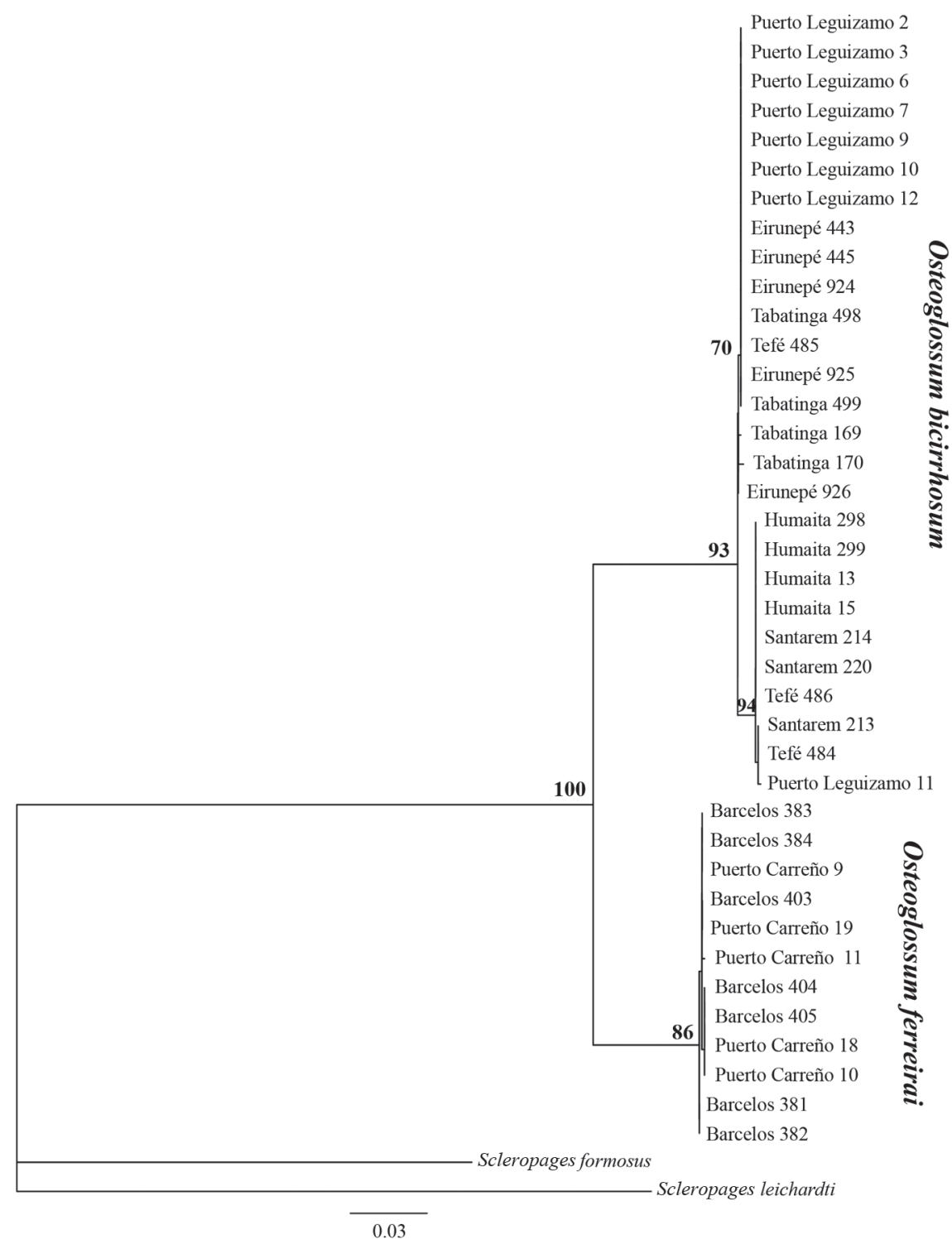

Fig. 2. Maximum likelihood phylogenetic hypothesis of relationships of Osteoglossum individuals representing the species $O$. bicirrhossum and $O$. ferreirai.

Distribution: Negro River basin, including the affluent Branco River; Orinoco River basin.

\section{Discussion}

Phylogenetic and Population Aggregation Analysis clearly separate and diagnose the two species of Osteoglossum, and place the Colombian populations within the species $O$. ferreirai. This diagnosis confirms that of Cala (1973). There were no unique haplotypes in the Orinoco basin samples of $O$. ferreirai, indicating a very recent divergence of the populations of the Orinoco and Negro River basins. We suggest that the lack of divergence of the Orinoco basin samples is most likely due to a recent introduction from the
Negro to the Orinoco river basin. Based on ichthyofaunal surveys of areas that can potentially serve as biological corridors and links between the two basins such as the Casiquiare channel and the floodplain of the Inirida and Atabapo Rivers, neither O. ferreirai nor O. bicirrhossum is

Table 1. Table of K2P distances (Kimura, 1980) between the two species of Osteoglossum and the Negro and Orinoco River populations of $O$. ferreirai.

\begin{tabular}{lcc}
\hline & O. bicirrhossum & O. ferreirai Negro \\
\hline O. ferreirai Negro & 0.0892 & \\
O. ferreirai Orinoco & 0.0897 & 0.0009 \\
\hline
\end{tabular}


Table 2. Table of intraspecific and intragroup K2P distances (Kimura, 1980) observed in the two species of Osteoglossum and the Negro and Orinoco River populations of $O$. ferreirai.

\begin{tabular}{cc}
\hline O. bicirrhossum & 0.0042 \\
O. ferreirai Negro & 0.0010 \\
O. ferreirai Orinoco & 0.0010 \\
\hline
\end{tabular}

present in these areas (Maldonado-Ocampo, et al., 2006; Maldonado-Ocampo, et al., 2008; Winemiller et al., 2008; Lasso, et al., 2009; Miller-Hurtado, et al., 2009; Winemiller \& Willis, 2011). Additionally, based on fauna surveys (Cala, 1973; Mojica, 1999; Lasso et al., 2005; Maldonado-Ocampo et al., $2006 ; 2008$ ) the expansion in the distribution of $O$. ferreirai in Colombia appears to have proceeded from north to south, i.e. towards the Negro River basin. Therefore, we consider it highly unlikely that the occupation of the Orinoco basin would proceed via geographically intermediate areas between the Orinoco and Negro basins. Natural long distance dispersal and colonization also appears an unlikely mechanism. Although we could not find any reference or report that would suggest that $O$. ferreirai in the Orinoco basin was or could have been introduced, we consider an introduction the most likely explanation. The area of origin of $O$. ferreirai from the Orinoco basin is unclear, however, and will require a detailed characterization of $O$. ferreirai from the Negro basin.

The possibility and what we consider to be the most likely scenario that $O$. ferreirai has been introduced in the Orinoco basin, constitutes a management and conservation dilemma. The Orinoco $O$. ferreirai have genetic diversity comparable to that of the fishes found in the Negro River basin, and appear to have expanded their geographic distribution. Thus they appear likely to increase in density and expand geographically if an ecological opportunity presents itself. On one hand, O. ferreirai makes an important contribution to the local economy, and is a highly desirable export species in the aquarium trade. In the Orinoco basin it appears to be over-exploited (Alvarez-León, 2002b; CCI, 2009), hence implementing a management and/or conservation program may result in not only its recovery, but also its expansion to other areas where it is currently not found. Being a top of the pyramid predator, and predating not only aquatic but also terrestrial vertebrates, could have a major impact on population ecology of the areas where densities $O$. ferreirai will increase. On the other hand, conservation programs normally try to eliminate introduced species. However, it seems unlikely that a program to eradicate $O$. ferreirai would succeed due to the area already colonized, and the remoteness of these areas. A third option is to do nothing. Under this scenario, the global aquarium market will largely determine if the species increases in density and colonizes new areas, remains at status quo, or its densities will decrease and possibly will even experience local extinctions. Ultimately, however, conservation and management decisions will be mandated by governmental agencies and will likely tend to balance socioeconomic needs with environmental protection.

\section{Acknowledgments}

We thank the Colombian Institute for Rural Development (INCODER), under-institute of Fisheries and Aquiculture, and the National University of Colombia with the support of the project "Evaluación biológico-pesquera de la arawana azul y la sapuara". Financial support was provided by $\mathrm{CNPq} /$ COLCIENCIAS cooperative grant \#490682/2010-3 to TH. TH and IPF were supported by a Bolsa de Pesquisa scholarship from $\mathrm{CNPq}$ during the study. MDE is supported by a fellowship from CAPES.

\section{Literature Cited}

Alvarez-León, R. 2002a. Osteoglossum bicirrhosum Pp. 168-170. In: Mojica, J. I., C. Castellanos, J. S. Usma \& R. Alvarez-León (Eds.). Libro rojo de peces de aguas dulces de Colombia Serie Libros Rojos de Especies Amenzadas de Colombia. Bogotá, Colombia, Instituto de Ciencias Naturales Universidad Nacional de Colombia, Instituto Alexander von Humboldt, Ministerio de Medio Ambiente.

Alvarez-León, R. 2002b. Osteoglossum ferreirai. Pp. 121-122. In: Mojica, J. I., C. Castellanos, J. S. Usma \& R. Alvarez-León (Eds.). Libro rojo de peces de aguas dulces de Colombia Serie Libros Rojos de Especies Amenzadas de Colombia. Bogotá, Colombia, Instituto de Ciencias Naturales Universidad Nacional de Colombia, Instituto Alexander von Humboldt, Ministerio de Medio Ambiente.

Cala, P. 1973. Presencia de Osteoglossum en los Llanos (Orinoquia). Acta Zoologica Colombiana, 18: 8.

Carroll, R. L. 1988. Vertebrate Paleontology and Evolution. New York, NY, W. H. Freeman and Company, 698p.

CCI (Corporación Colombia Internacional), 2009. Captura y comercialización de la arawana. Sistema de Información de Pesca y Acuicultura. Boletin mayo 17p. http://www.cci.org.co/cci/ cci_x/datos/BoletinesIncoder/Mensual/BolMay2009.pdf (Accessed 14 February 2009).

Cook, L. G., R. D. Edwards, M. D. Crisp \& N. B. Hardy. 2010. Need morphology always be required for new species descriptions? Invertebrate Systematics, 24: 322-326.

Davis, J. I. \& K. C. Nixon. 1992. Populations, genetic variation, and the delimitation of phylogenetic species. Systematic Biology, 41: 421-435.

Doyle, J. J. \& J. L. Doyle. 1987. A rapid DNA isolation procedure for small quantities of fresh leaf tissue. Phytochemical Bulletin, 19: 11-15.

Gutiérrez, M., Y. López-Pinto \& A. I. Sanabria. 2009. Aspectos reproductivos de la "arawana azul", Osteoglossum ferreirai Kanazawa, 1966 (Osteoglossiformes: Osteoglossidae), durante el ciclo hidrológico de mayo de 2007 a mayo 2009 en el río Bita (Vichada), Colombia, p. 134. In: X Simposio Colombiano de Ictiología, II Encuentro Colombo-Venezolano de Ictiólogos, I Encuentro Suramericano de Ictiólogos. Vol. 31. Actualidades Biológicas, Medellin, Colombia.

Hall, T. 1999. BioEdit: a user-friendly biological sequence alignment editor and analysis program for Windows 95/98/NT. Nucleic Acids Symposium Series, 41: 95-98.

Hasegawa, M., H. Kishino \& T. A. Yano. 1985. Dating of the humanape splitting by a molecular clock of mitochondrial DNA. Journal of Molecular Evolution, 22: 160-174. 
Hrbek, T., I. P. Farias, M. Crossa, I. Sampaio, J. I. R. Porto \& A. Meyer. 2005. Population genetic analysis of Arapaima gigas, one of the largest freshwater fishes of the Amazon basin: implications for its conservation. Animal Conservation, 8: 297308.

Jobb, G., A. v. Haeseler \& K. Strimmer. 2004. TREEFINDER: a powerful graphical analysis environment for molecular phylogenetics. BMC Evolutionary Biology 4: 1-9.

Kanazawa, R. H. 1966. The fishes of the genus Osteoglossum with a description of a new species from the rio Negro. Ichthyology and Aquarium Journal, 37: 161-172.

Kimura, M. 1980. A simple method for estimating evolutionary rates of base substitutions through comparative studies of nucleotide sequences. Journal of Molecular Evolution, 16: 111120.

Kumazawa, Y. \& M. Nishida. 2000. Molecular phylogeny of osteoglossoids: A new model for Gondwanian origin and plate tectonic transportation of the Asian Arowana. Molecular Biology and Evolution, 17: 1869-1878.

Lasso, C. A., J. I. Mojica, J. S. Usma, J. A. Maldonado-Ocampo, C. DoNascimiento, D. C. Taphorn, F. Provenzano, O. Lasso-Alcalá, G. Galvis, L. Vásquez, M. Lugo, A. Machado-Allison, R. Royero, C. Suárez \& A. Ortega-Lara. 2005. Peces de la cuenca del río Orinoco. Parte I: lista de especies y distribución por cuencas. Biota Colombiana, 5: 95-157.

Lasso, C. A., J. S. Usma, F. Villa, M. T. Sierra-Quintero, A. OrtegaLara, L. M. Mesa, M. A. Patiño, O. Lasso-Alcalá, M. A. Morales-Betancourt, K. González-Oropesa, M. P. Quiceno, A. Ferrer \& C. F. Suárez. 2009. Peces de la estrella fluvial Inírida: ríos Guaviare, Inírida, Atabapo y Orinoco (Orinoquia colombiana). Biota Colombiana, 10: 89-122.

Librado, P. \& J. Rozas. 2009. DnaSP v5: A software for comprehensive analysis of DNA polymorphism data. Bioinformatics, 2: 1451-1452.

Maldonado-Ocampo, J. A., M. Lugo, J. D. Bogotá-Gregory, C. A. Lasso, L. Vásquez, J. S. Usma, D. C. Taphorn \& F. Provenzano R. 2006. Peces del río Tomo, cuenca del Orinoco, Colombia. Biota Colombiana, 7: 113-128.

Maldonado-Ocampo, J. A., R. P. Vari \& J. S. Usma. 2008. Checklist of the freshwater fishes of Colombia. Biota Colombiana, 9: 143-237.

Miller-Hurtado, H., D. C. Taphorn B. \& J. S. Usma. 2009. Lista preliminar de los peces del río Papunahua, cuenca del río Inírida - departamento del Vaupés, Colombia. Biota Colombiana, 10: 163-169.

Mojica, J. I. 1999. Lista preliminar de las especies de peces dulceacícolas de Colombia. Revista de la Academia Colombiana de Ciencias, 23: 547-566.
Nelson, J. S. 2006. Fishes of the World, 4th Edition. New York, NY, John Wiley \& Sons, $624 \mathrm{p}$.

Posada, D. \& K. A. Crandall. 1998. MODELTEST: Testing the model of DNA substitution. Bioinformatics, 14: 817-818.

Rabello-Neto, J. G. 1999. Biologia reprodutiva e alimentação natural do Arauanã preto Osteoglossum ferreirari (Kanazawa, 1966), no municipio de Barcelos, Médio rio Negro, Amazonas, Brasil. Unpublished Dissertation, Universidade Federal do Amazonas (UFAM), Manaus, AM, Brazil. 32p.

Rabello-Neto, J. G. 2002. Variabilidad morfológica do aruanã preto, Osteoglossum ferreirai (Kanazawa, 1966) em seis área de pesca do médio Rio Negro, município de Barcelos, AM, Brasil: Implicações para a identificação de estoques. Unpublished Dissertation, Instituto Nacional de Pesquisas da Amazônia (INPA) and Universidade Federal do Amazonas (UFAM), Manaus, AM, Brazil. 45p.

Reis, R. E., S. O. Kullander \& C. J. Ferraris (Eds.). 2003. Check List of the Freshwater Fishes of South and Central America. Porto Alegre, Brazil, EDIPUCRS, 734p.

Tamura, K., D. Peterson, N. Peterson, G. Stecher, M. Nei \& S. Kumar. 2011. MEGA5: Molecular Evolutionary Genetics Analysis using maximum likelihood, evolutionary distance, and maximum parsimony methods. Molecular Biology and Evolution, 28: 2731-2739.

Thompson, J. D., D. G. Higgins \& T. J. Gibson. 1996. CLUSTAL $\mathrm{W}$ : improving the sensitivity of progressive multiple sequence alignment through sequence weighting, position specific gap penalties and weight matrix choice. Nucleic Acids Research, 22: 4673-4680.

Watkins, G., W. Saul, E. Holm, C. Watson, D. Arjoon \& J. Rjoon. 2004. The fish fauna of the Iwokrama forest. Proceedings of the Academy of Natural Sciences of Philadelphia, 154: 39-53.

Winemiller, K., López-Fernández, H., Taphorn D., Nico L. G \& B. Duque. Fish assemblages of the Casiquiare river, a corridor and zoogeographical filter for dispersal between the Orinoco and Amazon basins. Journal of Biogeography, 35: 1551-1563

Winemiller K \& S Willis. 2011. The Vaupes Arch and Casiquiare Canal barriers and passages. Pp 225 - 242 In James S Albert J \& Roberto E. Reis (Eds). Historical Biogeography of Neotropical Freshwater Fishers. University of California Press, 369 p.

Yue, G. H., D. Ong, C. C. Wong, L. C. Lim \& L. Orban. 2003. A strain-specific and a sex-associated STS marker for Asian arowana (Scleropages formosus, Osteoglossidae). Aquaculture Research, 34: 951-957.

Submitted January 23, 2012 Accepted February 26, 2013 by Claudio Oliveira Published June 28, 2013 